\title{
What Determines HIV Self-Test Acceptability and Uptake Within The MSM Community in Nairobi and Its Environs? A Cross Sectional Study
}

Kingori Ndungu ( $\square$ kingoriindungu@gmail.com )

Universiteit Gent https://orcid.org/0000-0002-9919-7012

Peter Gichangi

University of Nairobi College of Health Sciences

Marleen Temmerman

Aga Khan University - Kenya

Research article

Keywords: MSM, MSW, HIVST, HIV Testing

Posted Date: July 27th, 2020

DOI: https://doi.org/10.21203/rs.3.rs-31416/v1

License: @ (1) This work is licensed under a Creative Commons Attribution 4.0 International License. Read Full License 


\section{Abstract}

Background: Human Immunodeficiency Virus self-test (HIVST) refers to a process where a person collects his or her own specimen (blood or oral), performs a test and interprets the results. The interpretation of results can either be done in private or through support of a trusted partner. Self-test should be seen as screening and confirmatory test should be sort.

Study Objective: To determine facilitating factors for HIVST acceptability and uptake among MSM community.

Methods: The researcher employed a cross-sectional exploratory study design, targeting men who have sex with men (MSM) and men sex workers (MSW). The researcher used purposive sampling to identify the sites where data was collected, snowballing techniques were then employed to reach the respondents.

Results: There was a significant association between self-test and frequency of testing for HIV/AIDS at P-Value of 0.011. Eighty three percent $(83 \%)$ of the respondents had a negative HIV test result, $(16 \%)$ had a positive result from the previous result. Most of the MSM will seek for confirmatory test, if tested HIV positive through HIVST. Majority of the MSM respondents indicated they would go for counselling after testing positive. Healthcare workers advocated for pre-testing counselling. There was also a significant association between respondents who had never tested using self-test kits and the need for a treatment "buddy" with a P-Value of 0.014. Fifty nine percent of the respondents would prefer blood sample test kits, the kits were seen to be more accurate than oral test kits. High cost of the self-test kits and inadequate knowledge on the use of HIV self-test kits were the main hindrances to HIVST uptake.

Conclusions: A significant number of MSM community in Kenya are willing to use HIVST and are likely to seek for care within 30 days of self-testing and this is a good indicator of linkage. Blood sample kits are more preferred. Key facilitating factors for HIVST uptake include; awareness creation on the importance of HIVST and training on usage of kits, emphasis on treatment "buddy" for first time testers and reduction on cost of the kits.

\section{Background}

HIV prevalence among key populations in Kenya is disproportionally high (18.7\%), compared with the general population (6\%). Whereas key populations in Kenya account for less than $2 \%$ of Kenya's population, it is estimated that key populations account for $33 \%$ of new infections [1]. Through the ambitious 90-90-90 global strategy, the United Nations Programme on HIV/AIDS (UNAIDS) advocates that at least $90 \%$ of people should know their HIV status, $90 \%$ of those diagnosed linked to anti-retroviral (ARV) treatment and $90 \%$ of those on treatment achieving viral suppression [2]. Achieving "the first 90\%" is a critical step in the elimination of new infections by 2030 [3].

A significant number of HIV positive individuals in Sub-Saharan (SSA) are not aware of their HIV sero-status, more than half (53\%) of the 1.6 million people living with HIV in Kenya are unaware of their HIV status [4]. There is therefore urgent need to develop and implement innovative initiatives that promote HIV testing, especially among key population such as among the MSM community.

HIV self-testing (HIVST) involve a process where an individual collects their own specimen (oral fluid or blood), conducts a HIV test and interprets the result. Individuals can perform a HIV self-test in a private setting, either alone or with someone they trust. The Kenyan government introduced self-testing kits as part of "Be Self Sure campaign in May, 2017. The kits are now available to buy from pharmacies for around 8-10 United States Dollars (USD). Since HIV self-testing does not provide a definitive diagnosis. Individuals whose tests positive for HIV are advised to seek confirmatory testing with a health provider, in line with the national HIV testing algorithm [5]. Recent research conducted in Zimbabwe, Zambia, Lesotho and Kenya revealed that HIVST is feasible, acceptable among health workers and the general population [6], [2], [7]. Generally, uptake of HIV Testing Services (HTS) among the key population is low, compared to those in the general population due to barriers such as stigma, discrimination and poor quality of services [8], [9]. There is potential for HIVST to enhance access to HIV testing [10]. 区Innovative interventions geared towards promoting testing among the MSM community must overcome key barriers to testing such as stigma, fear about confidentiality of venue testing, distance to testing sites and opportunity cost. Countries around the world are at different stages of development and implementation of HIVST guidelines. There is however no optimal approach for implementing HIVST targeting key population and the MSM community. There is also insufficient evidence on the acceptability of HIVST among the health care workers who are expected to promote the uptake of HIVST among MSM clients and other key populations. We conducted research to explore acceptability and factors that would facilitate the uptake of HIVST among the MSM community in Nairobi.

\section{Methods}


This exploratory study employed a cross-sectional design with mixed methods in peri-urban settings of Nairobi and Kiambu Counties in Kenya. Our study population was adult men (aged 18-60 years) that reported to be actively engaging in anal or oral sex with men. The age requirement for over 18 years intended to preclude any ethical issues surrounding the interviewing of MSM minors.

\section{Sampling techniques and sample size.}

We recruited a total of 391 MSM respondents to complete self-administered questionnaires, some of the respondents were men sex workers (MSW). Only 369 MSM completed the questionnaires (response rate $=94 \%$ ). For respondents to be eligible to participate in this study, they had to be aged between 18-60 years. Only self-reported MSM aged above 18 years of age were eligible to participate in this study. We used FGD to gather more information on the respondent's opinion on the themes of interest. Since, the MSM and MSW community is a hidden population and difficult to reach, especially in Kenya where homosexuality is criminalized, we purposively sampled eleven data collection points from where the MSM frequent for the FGD. The areas include the drop-in centers, bars, hotels and massage parlors. Snowballing was then employed to reach the respondents. The researcher also purposively selected five healthcare facilities for the FGD from a list of MSM friendly NGO clinic and government facilities offering MSM healthcare services. Random sampling was then used to reach the respondents who included the doctors, clinical officers, nurses, laboratory technicians and counsellors.

\section{Data collection:}

All the MSM respondents completed paper based self-administered structured questionnaires between July 2018-June 2019 after obtaining oral informed consent. These structured questionnaires consisted of three sections. The first section had questions on demographics of the respondents. The second section consisted of questions on HIV risk behaviors. The final sections had question on HIVST. We conducted four FGDs with health workers in five facilities. Using a discussion guide, we explored healthcare workers perception on HIVST, HIV risk factors within the MSM community, preference on the pickup points for the testing kits, perceptions on current cost of testing kits, concerns of task shifting and when counseling should be conducted. Each FGD had an average of ten participants and lasted between sixty to seventy-five minutes. We also conducted five FGDs with the MSM community. Each FGD had an average of twelve discussants that lasted between seventy to ninety minutes. The following topics were explored; HIV risk factors, condom use after positive test, when to conduct counselling, HIVST kit type preference, opinion on the current cost of test and preference of kits pickup points. We dealt with saturation by continuously analyzing the transcripts until there were no new themes emerging from the FGDs.

\section{Data Analysis \& Management}

The questionnaires were serialized and data entered in a SPSS Version 23.0 data-base for analysis (IBM Corp, 2015). Using descriptive analysis, we summarized and presented data in tables. We cross tabulated data on factors associated with HIV self-test uptake among the MSM community. Further analysis of inferential statistics was conducted using Odds Ratio (OR) and Risk Ratio (RR) tests. This estimated the contribution of each of the risk factors in the outcome of HIV self-test uptake among the MSM community. Qualitative data from the FGDs were transcribed verbatim and coded using NVIVO version 12 software (QSR International Pty Ltd; 2018). We used inductive coding to generate new categories for summarizing narratives on emerging themes from the transcripts. The themes that were similar in FGD and quantitative analysis were triangulated.

\section{Ethical Considerations}

We ensured full compliance to the research ethics codes set out in the Helsinki Declaration. Ethical clearance was obtained from the University of Ghent Approval number (PA 2016/009) and the Mount Kenya University Ethics Review Committee (Approval number: $\mathrm{MKU} / \mathrm{ERC} / 0463$ ). Informed consent was obtained from all study participants in a language that they could understand and were informed that their participation was voluntary. To ensure confidentiality, all potential identifiers in the data were omitted and each record was anonymized using unique identifiers during data entry and analysis. Access to the data was restricted to only those researchers responsible for analysis in password protected databases and computers. All investigators received extensive training on research ethics at the beginning of the study.

\section{Results}

The results are presented in two sections. The first table and sections contain the demographics, social-economic and HIV risk for the respondents, the second sections data on the results for HIVST.

\section{Demographics, Socio-economic \& HIV Risk characteristics of participants}


The majority of respondents were Kenyans at (92.6\%), followed by Ugandans at (4.0\%), Democratic Republicans of Congo and Rwandans were equal at $(1.1 \%)$ respectively, Tanzanians $(0.6 \%)$, Cote D'voire and Nigerians were distributed equally at $(0.3 \%)$. A significant number of the respondents indicated that their income band was less than 60 USD at (49.3\%), and USD $60-250$ at (39.3\%), with (9\%) at USD 251 750 and $(2.4 \%)$ at over USD 750 . This means that $87 \%$ of the respondent's monthly income range between USD

$0-250$. Half of the respondents at (50\%) of the respondents identified themselves as men sex workers (MSW). Most of the respondents were homosexual followed by bisexual. About sixty eight percent (68\%) of the respondents were ever married to a man and (28\%) had been ever married to a woman. A majority of the respondents indicated that they had multiple sexual partners at (39.9\%), those who indicated that they had two sexual partners in the past six months were (33.6\%), the respondents who indicated to have had only one sexual partner in the period were $(21.1 \%)$ with $(5.4 \%)$ of the respondents indicating that they had no sexual partner in the last six months. Most of the respondents were versatile, they preferred being either on top or bottom. The above data is available on $(T a b l e, 1)$ below.

\section{Results on HIV self-test uptake.}

\section{Frequency of HIV/AIDS test}

Among the MSM who have ever tested for HIV/AIDS, 246 (67\%) of respondents had tested for HIV within 3 months retesting frequency and were the majority, while the respondents with more than 3 months retest at $121(33 \%)$ with $44(36.4 \%)$ having used self-test. There was a significant Chi-Square association between self-test and frequency of testing for HIV/AIDS P. Value $=0.011$. The respondents with testing frequency greater than 3 months were 1.386 times as likely to test using a HIV self-test kit before.

\section{Result of the most recent HIV test}

Seventy six percent of the respondents (76\%) 280 of the respondents had a negative result, 87 (24\%) had a positive result from the last result. Among the clients who tested negative 134 (47.9\%), had used HIV self-test kits and among those who tested positive 34 (39\%) had also used HIV self-test kits.

\section{Considered window period in deciding when to test}

Forty six percent of the clients (46\%) 169 of the respondents indicated that they consider window period before testing and among them 86 (50.9\%) had used self-test kit. 198 (54\%) said they did not consider window period when testing.

\section{STI screening frequency}

The respondents who indicated that they screen for STI after 0-3 months were the majority at $280(77 \%)$, over three months were at 86 (23\%) of the respondents. There was a statistically significant Chi-Square dependency between respondents who had ever used a HIV selftest kit and the respondents STI screening frequency at P. Value $=0.005$. The respondents who's STI screening frequency was over three months was at 1.525 times likely to test using a HIV self-test kit.

\section{HIVST acceptability.}

A significantly high population of the MSM at $76 \%$ considers HIV self-test as one of the HIV prevention combination prevention strategies with (47.9\%) having used HIV self-test kits

\section{Ever heard of HIV self-test}

The interviewees who had ever heard of HIV self-test were 231 (63\%) with 121(52\%) indicating that they had used the HIV self-test kit. There was a statistically significant Chi-Square association between HIV self-test kit use and the respondents who had ever heard of a HIV self-test kit at P. Value $=0.001$. The respondents who had ever heard of a HIV self-test kit were 1.374 times likely to test using a HIV selftest kit.

\section{Ever heard of oral HIV Self-test}

The respondents who had ever heard of oral HIV self-test 205 (56.0\%) with $113(55.1 \%)$ of this respondent who had used a HIV self-test kit. There was a statistically significant Chi-Square association between respondents who had ever used a HIV self-test kit and the respondents who had ever heard of an oral HIV self-test kit at P. Value $=0.0001$. The respondents who had ever heard of oral HIV self-test kit were 1.472 times likely to test using a HIV self-test kit. 


\section{Ever heard of blood sample HIV Self-test}

The respondents who had ever heard of blood sample HIV self-test were 259 (71\%) with $143(55.2 \%)$ of this respondent who had used a HIV self-test kit. There was a statistically significant Chi-Square association between respondents who had ever used a HIV self-test kit and the respondents who had ever heard of a blood sample HIV self-test kit at P-Value $<0.0001$. The respondents who had ever heard of blood sample HIV self-test kit were 1.716 times likely to test using a HIV self-test kit.

\section{Would prefer to use the Oral or Blood self-test kit}

About fifty nine percent (59\%) 181 of the respondents indicated that they would prefer a blood self-test kit with $89(49 \%)$ of the respondents having used the self-test kit. About forty one percent (41\%) 126 of the respondents of the respondents indicated that they would prefer an Oral self-test kit with $141(45.9 \%)$ of the respondents having used either self-test kit. There was a statistically significant Chi-Square association between respondents who had ever used a HIV self-test kit and the respondent's preference to use either the Oral or Blood self-test kit at $P$. Value $<0.0001=0.039$. The respondents who would prefer to use the Oral or Blood self-test kit were 1.243 times likely to test using a HIV self-test kit. There were mixed reactions on the preferred HIVST kit among the respondents who took part in the FGD for MSM and Key informant interviews from the healthcare workers. Oral self-test kits are preferred because they were easier to use and they did not require any pricking and were easily disposed. They were also reported to be less complicated. Blood self-test kits were preferred because they were considered more accurate, use of blood was considered more reliable for HIV testing, hence it would be easier to convince a client to take up a test. Below are few excerpts of the findings;

"To me I prefer oral because it is a self-test and it is easier for clients to use it and even disposing it is easier compared to the blood ones." (Clinical Officer). "Personally, I think it would be oral, would want to give the oral which I think would be easier to explain to the client to apply the procedures and then most clients don't like being pricked." (Nurse)

"...for me I would go with the blood because even scientifically you know the HIV virus will target the cells which are in the blood but now these other science of using the mucus membrane a bit looks tricky...you need to convince this client that you are not targeting the saliva but you want the lining of the mucus membrane this patient may fail to understand what is this mucus membrane... you find that reliability of this test might bring conflict of interest." (Clinical Officer).

\section{What would prevent you from using the HIV oral test kit}

Thirty three percent (33\%) 104 of the respondents indicated that cost would prevent them from using the HIV oral self-test kit with 40 (38\%) of the respondents having used a HIV self-test kit. Thirty two percent (32\%) indicated that lack of knowledge would prevent them from HIV oral self. Inaccessibility and fear of the results were also some of the other reasons that were mentioned.

\section{What would prevent you from using the HIV blood self-test kit}

Twenty nine percent (29\%) 89 of the respondents indicated that cost would prevent them from using the HIV blood sample self-test kit with $27(30 \%)$ of the respondents having used a HIV self-test kit. Lack of knowledge of how to use the kits, fear of the results and inaccessibility of the kits were some of the other reasons that would hinder the respondents from using the blood sample test kits.

\section{HIV positive through HIV self-test, would go for a confirmatory test}

A high proportion of the respondents at $292(80 \%)$ indicated that if they tested HIV positive through HIV self-test, they would go for a confirmatory test and among this respondent $135(46.2 \%)$ had used a self-test kit, $75(20 \%)$ indicated they would not go for a confirmatory test. There was a significant Chi-Square association between going for a confirmatory test if tested HIV positive through HIV self-test at $P$. Value $=0.031$. The respondents who would go for a confirmatory test if tested HIV positive through HIV self-test were 1.386 times as likely to test using a using a HIV self-test kit.

\section{After how long would you go for a confirmatory test}

About (92\%) 332 indicated that they would go for a confirmatory test after within a month while $28(8 \%)$ indicated they would not go to confirm the test.

\section{Protection/Condom use after a positive test with your partner}

Eighty six percent (86\%) 315 of the respondents indicated that they would use protection/condom after a positive test with the partner and among them $152(48.3 \%)$ had used a self-test kit. There was a statistically significant relationship between self-test kit use and the 
respondent's protection/ condom use after a positive test with their partners at P. Value $=0.019$. The respondents who use protection or condoms with their partners were 1.338 times as likely to test use a HIV self-test kit. There were mixed reactions on the use of condoms after a positive HIV test with one respondent from the FGD reporting that condoms would only be used by a discordant couple and would not be used if both partners were concordant positive; "You go tested with your partner, if you are both positive there is no need, if one of you is negative then you use condoms"

\section{Counselling after positive results.}

A majority of the respondents indicated that they would go for counselling after positive results at 169 (46\%) with 85 (50.3\%) among the respondents having used a self-test kit. Majority of the study respondents from the FGD reported on the need for pre-test counselling before HIVST as this would provide an opportunity for clients to get all the information, they needed to make a decision after a HIV test and know where to go for follow up.

"It is usually accessed at a government facility, so even this self-test can be designated to specific pharmacies, the pharmacies should have a counseling room and should have a counselor who is sensitive and who has all the information about the HIVST and who can counsel for that such that there are no repercussions after the test and if you test positive, already you've been given the information you have them their so you know where to go, what to do and how to do a follow up.

\section{Use condoms with partner after a negative test result}

Eighty nine percent (89\%) 325 of the respondents agreed that they would use condom with their partners despite a negative HIV test result and 155 (47.7\%) indicated that they had used a HIV self-test kit. There was a statistically significant Chi-Square relationship between HIV self-test kit use and the respondent's condom use with partners even after a negative HIV test result at P. Value $=0.040$. The respondents who tested negative and who would use condoms with their partner were 1.338 times as likely to test using a HIV self-test kit. FGD study respondents reported that they would also use condoms after a negative HIV test because it would prevent them from other diseases (STIS), it would prevent them should their partner be in the HIV window period or prevent them from HIV should the viral load of the sexual partner be undetectable.

\section{Opinion on current cost}

About sixty two percent of the respondents indicated that the estimated current market cost of the self-test kit was expensive with 120 (56.6\%) having used the self-test kit. The respondents who felt that the current estimated self-test kit was affordable were at 155 (45.9\%) and $48(31 \%)$ among them had used a HIV self-test kit. There was a statistically significant Chi-Square relationship between cost of the test kits and use at a P-Value $<0.0001$. The respondents who thought that the current cost was expensive were 1.591 times not likely to test using a HIV self-test kit. The preferred cost of a HIVST kit was reported to be about 1 USD. One respondent reported that the cost of a kit should be free of charge for MSM. It was reported that there should be considerations for the job status of the client. Further it was reported that there should be considerations of cost for MSW who require frequent testing as captured by the following excerpt; "For instance the case of MSW, that person needs like frequent testing, you can't say if the kit is going for let's say 5 USD that person is going to use like 150 USD for 3 months for testing. You know this person is looking for money to feed themselves and then you start telling them about testing themselves?"

\section{Preference point of picking the oral HIV self-test kit or what distribution channel would you prefer}

A majority of the respondents at 169 (52.8\%) indicated that they would prefer NGO facility/drop in center's as distribution point, 70 (21.9\%) indicated they would prefer to pick the test kits from the nearest government facility, 36 (11.6\%) indicated that their point of preference to pick the kits to be Private hospital/Private clinic, the respondents who indicated that they would prefer to pick the kits from a retail or community pharmacy were 34 (10.9\%). There was a recommendation from the FGD discussion that the government should be involved in the supply and provision of the HIVST kits; "Maybe the government should come up with a policy that the pharmacies should not sell these test kits; there should just be a place where people will be taking them." One respondent however reported that local pharmacies would not be suitable to obtain HIVST kits as captured by the response below excerpts; "these people you know they know me, I know them, so whenever I am interacting with them they will know who I am and that one can expose me to security (insecurity)." In contrast however, another respondent reported that because the HIVST kit was for use by everyone, buying from a local pharmacy would not expose an MSM. "the self-test, is not for you personally, it's not for MSM only, even people outside there they need the test, so if you go ask for a selftest they will not know and start stigmatizing you. You will just buy as you buy credit (airtime)".

\section{If test kit were to have hotline, which institution or organization would you prefer to provide the information}


About (45\%) 142 of the respondents indicated that they would prefer the hotline to be handled by a Drop in Centre with 65 (46\%) among respondents having used the HIV self-test kit. 91(29\%) indicated that they would prefer the information from the hotline relayed from a public hospital with 41 (45\%) among this respondent having used a HIV self-test kit.

\section{Using self-test for the first time would you prefer to have a treatment "buddy"}

About sixty seven percent (67\%) 207 of the respondents indicated that they would prefer a treatment buddy on the first time of self-test kit use with 108 (52\%) of the respondents having used the self-test kit. There was a statistically significant Chi-Square association between respondents who had never used a HIV self-test kit and the respondents need of a treatment partner on first time use of HIV self-test kit at P. Value $=0.014$. The above table is available on (Table, 2) below.

\section{Discussion}

This study majored on HIVST among the key population and specifically the MSM community in Nairobi and the peri-urban areas neighboring. The findings of this study significantly contributes to WHO's 2016 guidelines on HIVST that calls for further evidence of HIVST in the key population especially among the MSM community in Kenya [11].

The study explicitly shows there is a significant Chi-Square association between HIV self-test and frequency of testing at a P-Value of 0.011. The respondents who had tested for HIV with 3 months retesting frequency were the majority of the respondents who had used HIV self-test kit at (51\%). Our findings are in concurrence with MSM randomized to HIVST access Vs. standard clinic-based testing in Seattle, the mean number of HIV test and quarterly testing increased significantly among those in the HIVST, with no increase in risk behaviors [12]. Kenya's National HIV testing guidelines recommends re-testing of HIV negative key populations every three months [13]. To achieve the above target, both clinic-based setting and HIV self-test options should be scaled up among the MSM.

About fifty nine percent (59\%) of the respondents indicated that they would prefer blood sample self-test kit and $45.9 \%$ would prefer an oral self-test kit. These findings are in line with a study conducted in South Africa among the MSM community that showed higher preference for fingerstick tests over oral fluid tests among the participants [14]. Our findings differ from study findings conducted in the US emergency department, where most of the respondents prefered oral fluid testing [15]. Given the diversity of preference for either blood sample or oral test kits and the ovewhelming support for HIVST, we would highly recommend the availability and distibution of both types of self kits to the MSM in Kenya.

Many of the respondents indicated that they would go for confirmatory test after positive results at (46\%) with (53\%) among the respondents having used a self-test kit. Our findings are consistent with findings from a cross-sectional study done in Kenya that showed that $74 \%$ of the respondents would seek counselling services, confirm results or seek medication after a positive HIVST [16]. Majority of healthcare providers from the FGD reported on the need for pre-test counselling before HIVST as this would provide an opportunity for clients to get all the information they would need before testing. This provision of information before testing would be crucial in guiding the clients on how to use the test kits, so as to reduce invalid results also the clients would know what to do depending on the results and where to seek for the healthcare services.

Forty five percent of the respondents would prefer the hotline to be handled by a Drop in Center and (29\%) indicated that they would prefer the information from the hotline relayed from a public hospital. Findings from the MSM FGDs showed that the MSM would prefer to get information from You Tube, brochures, sensitizations, Drop-in-Centers outreaches, websites e.g. Ministry of Health website were reported as some of the preferred places to get HIVST information. A study done with a cohort of MSM in Nigeria showed less usage of the hotline or helpline. A low number of the participants $\square$ called through the helpline. This was expected, since most the respondents found the instructions easy to use to understand and use [17]. Other studies have also shown significantly low usage of the hotlines [18]. [19]. All the above options should be adopted in reaching out and providing more information on the use of HIV self-test kits and linking MSM to the health care systems.

A major concern for HIVST is whether self-testers will seek care and treatment depending on the results. Linkage to HIV care is seen as accessing a health care provider through a clinic at different stages, the stages include i) enrolment into care and treatment after diagnosis, ii) determination of antiretroviral therapy eligibility, iii) initiation of ART and iv) ART adherence [20]. Being able to link to care within a week is considered optimal behavior given that linkage to care is defined as "having visited a health care provider within 30 days of being diagnosed with HIV [21]. A significantly high proportion of the respondents at (92\%) would go for confirmatory test within one month of testing. Our findings are slightly higher to a study conducted by in Kenya in 2014, [16]. that reported 61\% of the general population sampled, $40 \%$ of MSM and $75 \%$ of female sex workers would go to a clinic for a confirmatory test. This demonstrates that the

Page $7 / 21$ 
MSM who self-test are willing and will still link to the healthcare system. During the implementation of HIV self-test, the following mixed approaches can be considered in linking the MSM to the healthcare services. Seventy eight percent (78\%) of the respondents would prefer to visit the MSM health facility and $21 \%$ would prefer home visits by healthcare providers. Other MSM would prefer calls and short message text (SMS) to be able to link with the health care systems. Most of the healthcare providers interviewed preferred phone calls as a means of follow up and linking the MSM to the healthcare facilities, since it's a very mobile sub-population. SMS was the least preferred, since it limits someone from expressing their concerns and feelings. The SMS platform was the least preferred as it was difficult to establish a relationship. Most of the respondents felt it was important for them to be able to express their concerns and feelings after receiving a positive result. This would be very difficult using the MSM. Scientific evidence indicates that being sick is a strong determinant to linkage to care as one seeks medical attention [20]. Hence the MSM who feel generally "healthy" though sero-positive but with no sign and symptoms are likely not to link to care. A study conducted in Nigeria among the MSM community showed a $100 \%$ linkage to HIV and treatment [17]. The high linkage in that study was likely due to follow-up calls after HIVST distribution, the ease of participant's access to the opinion leaders and also the linkage to a well-trusted MSM-friendly facility that offers HIV prevention services. Studies conducted in other areas reported both fairly low [22] and high [23], [24]. linkage to HIV care and treatment after self-testing.

A majority of the respondents at (52.8\%) indicated that they would prefer private/NGO facility/drop in center's as distribution point and $23.1 \%$ from the private sector and $21.9 \%$ would prefer public/Government facilities. Findings from the MSM FGD compliments the above findings. When asked about the most suitable place to obtain the HIVST kit; NGO facility/Drop in Centers, private sector and Public/ government facilities were preferred in that order. Our findings differ slightly with a study conducted by Okal et al., (2014) [25], that's showed that most of the respondents preferred public health care facilities but for the general population. The variance in the findings can be attributed to the fact that the MSM community feel stigmatized and also due to the illegal nature of homosexuality in Kenya, hence the MSM would want to stay far away from the public/Government healthcare providers. Site preference is also largely based on proximity and cost. A study conducted within the general adult population showed that "easily available" as the strongest reason for which ever pick up point [6]. The study shows that different distribution centers should be adopted to reach more MSM with the kits. A research conducted in Nigeria affirms the above preference of the MSM to pick the kits from the MSM friendly drop in centers, a high percentage (42.2\%) chose to go to the community health clinic (CHC) for the HIVST kits [17]. Future HIVST distribution should consider drop in centers and community pharmacies as options of distribution sites. Peer educators or Key Opinion leaders (KOL) are still an option to be considered, though this approach would have high cost implications.

A significantly high number of MSM at $84.4 \%$ indicated that they would prefer a treatment "buddy" on the first time of self-test kit use. There was a statistically significant association between respondents who had never used a HIV self-test kit and the respondents need of a treatment partner on first time use of HIV self-test kit. In the year 2013, Kenya conducted the first HIVST validation studies that reported a higher rate of invalid HIV results $(37 / 239=15.5 \%)$ [6]. The findings are also consistent with another study done among Chinese MSM, that showed significant errors during the process of conducting HIVST that rendered almost half of the test results invalid [26]. According to that study, failure to follow the manufacturers instructions was the main cause of invalid results both for oral self test and blood sample test kits. For the finger prick users, most of the errors occurred during the stage of collecting specimen and for oral fluid users made most of the errors during the stage of testing the collected specimen. A treatment partner or "buddy" should be advocated for in helping the MSM first time testers get accurate results. The above findings explicitly demonstrate the need for assisted testing for first time users to reduce the invalid tests and also the need for hotlines which are accessible 24 hours and are trusted and friendly to the MSM community to be able to seek help. Further to this, MSM should be encouraged and awareness created for anyone who gets an invalid result to immediately seek post-test counseling.

The high cost of the test kits, lack of knowledge on correct usage of the test kits, fear and inaccessibility of HIV self-test kits were the main hindrances on the use of the kits. Fifty three percent of the respondents (53\%) indicated that the estimated current market cost of the selftest kit was expensive at 8-100 USD. The healthcare workers also thought that the current cost of the HIVST is quite high they recommended a reduction in the cost. The healthcare providers preferred cost of a HIVST kit to be about half to one USD. One respondent reported that the cost of a kit should not exceed one USD. A significantly high percentage of the MSM at (32\%) indicated lack of knowledge would prevent them from using the HIVST. This correlates to studies showing several ways in which errors would happen, this would include during sample collection using the swab, also the handling of the swab and following the procedures [27, [6]. Data from the healthcare providers showed that stigma, lack of adequate information after HIVST were reported as negative factors affecting the uptake of HIVST. There are concerns from the healthcare providers that HIVST would render the HIV counselling \& testing providers jobless due to task shifting. However, from this study it is explicit that the healthcare providers are supporting and willing to scale up HIVST. The respondents felt that task shifting had not occurred because once a client visited a health facility even after a HIV self-test, they would still have to undergo HIV testing as per the national algorithm. There are also fears on the possible testing outcomes and the reactions of the 
MSM if the results are positive that would hinder the usage of the HIVST. This again shows the need for a treatment buddy for support during testing.

This study has some limitations. Despite the fact that the respondents, were recruited through methods designed to generate a representative sample, the sample is unlikely representative of all MSM in Kenya, since most of the respondents were young and of low and medium economic status. Demonstrating that the older and MSM with higher economic status were not represented. The respondents were also drawn from Nairobi and the neighboring county, where the MSM community has been receiving considerable support from the NGOs as compared to MSM in other regions of the country. Future studies should prioritize the elder generations and also the MSM with higher income status and also from other regions of the country with few HIV prevention interventions.

\section{Conclusions}

HIVST in Kenya will significantly contribute to the first United Nations 90-90-90 targets as many MSM remain unaware of their HIV serostatus [28]. A significant high proportion of the MSM consider HIV self-test as one of the HIV combination prevention strategies and are willing to be take-up HIVST. Most of the MSM are willing to seek for care within 30 days of self-testing. This is a good indicator for linkage to care and treatment after self-test. Some of the key facilitating factors for HIVST uptake among the MSM community in Kenya include; awareness creation on the importance of frequent HIV testing, sensitization on the importance of considering window period during testing, advocacy on the importance of confirmatory test after HIVST, counselling pre and/ or post testing, emphasizing the importance of treatment buddies for first- time testers and reducing the cost of the current HIV self-test kits. Blood sample test kits are more preferred than Oral test kits. Phone calls should be considered as a priority strategy for reach out to the MSM community and for linking them to care \& treatment after HIV self-test. Future studies should explore HIVST among the elder generations and MSM with higher economic status. Other studies should explore linkage to care and treatment of the MSM receiving the kits from the different distribution channels.

\section{Abbreviations}

\begin{tabular}{|ll|}
\hline ART & Antiretroviral Therapy \\
AIDS & Acquired Immunodeficiency Syndrome \\
HIV & Human Immunodeficiency Virus \\
HIVST & Human Immunodeficiency Virus self -test \\
MSM & Men who have sex with men \\
MSW & Pre-exposure prophylaxis \\
PEP & Post exposure prophylaxis \\
PrEP & Pre-exposure prophylaxis \\
\hline
\end{tabular}

\section{Declarations}

\section{Ethics approval and consent to participate}

Clearance for the study was obtained from Ghent University PA 2016/009 and Mount Kenya University Ref. No. MKU/ERC/0463. Verbal informed consent was sought before the interviews due to the illegal nature of homosexuality in Kenya and was approved by the ethics committee.

\section{Consent for publication}

Not applicable

\section{Availability of data and materials}

The datasets supporting the conclusions of this article are included within the article and its additional files. The attached questionnaire was developed purposely for this study.

\section{Competing interests}


The author declares no competing interests.

\section{Funding}

The study was funded by the author

\section{Authors' contributions}

All authors made significant contribution in the conceptualization and design of this study.

$\mathrm{KN}$ was responsible for the formulation of the study, conducting data collection, analyzing and developing the paper. GP and TM reviewed the paper and provided technical advice. All authors read and approved the final manuscript.

\section{Disclaimer}

The views and opinions expressed herein belong to the authors alone.

\section{Acknowledgements}

We thank all participants for supporting this study

\section{References}

1. National AIDS and STI Control programme (NASCOP). National Guidelines for HIV / STI Programming. Available from: http://www.icop.or.ke/wp-content/uploads/2016/10/KP-National-Guidelines-2014-NASCOP.pdf [Accessed $7^{\text {th }}$ May 2019].

2. Harichund C, Moshabela M. Acceptability of HIV Self-Testing in Sub-Saharan Africa:Scoping Study. AIDS Behaviour 2018; 22(2):560-8. Available from: http://www.ncbi.nlm.nih.gov/pubmed/28699017. [Accessed 20th June 2019].

3. Hayes RJ, Donnell D, Floyd S, Mandla N, Bwalya J, Sabapathy K, et al. Effect of universal testing and treatment on HIV incidenceHPTN 071 (popart). N Engl J Med. 2019;381(3):207-18.

4. NACC KENYA. Kenya AIDS progress report 2016. 2016;92. Available from: https://nacc.or.ke/wp-content/uploads/2016/11/KenyaAIDS-Progress-Report_web.pdf [Accessed 26th September 2019].

5. Pai NP, Sharma J, Shivkumar S, Pillay S, Vadnais C, Joseph L, et al. Supervised and Unsupervised Self-Testing for HIV in High-and Low-Risk Populations: A Systematic Review. 2013;10(4).

6. Kurth AE, Cleland CM, Chhun N, Sidle JE, Were E, Naanyu V, et al. Accuracy and Acceptability of Oral Fluid HIV Self-Testing in a General Adult Population in Kenya. AIDS Behaviour, 2016. 20(4):870-9. Available from: http://www.ncbi.nlm.nih.gov/pubmed/26438487. [Accessed 2nd April 2019].

7. Asiimwe S, Oloya J, Song X, Whalen CC. Accuracy of un-supervised versus provider-supervised self-administered HIV testing in Uganda: A randomized implementation trial. AIDS Behaviour, 2014 18(12):2477-84. Available from: http://www.ncbi.nlm.nih.gov/pubmed/24691923. [Accessed 16th May 2019].

8. Wei C, Cheung DH, Yan H, Li J, Shi L, Raymond HF. The Impact of Homophobia and HIV Stigma on HIV Testing Uptake among Chinese Men Who Have Sex with Men. JAIDS, 2015 1(1):1. Available from: http://www.ncbi.nlm.nih.gov/pubmed/26334742. [Accessed 13th February 2019].

9. Siedner MJ, Ng CK, Bassett I V., Katz IT, Bangsberg DR, Tsai AC. Trends in CD4 Count at Presentation to Care and Treatment Initiation in Sub-Saharan Africa, 2002-2013: A Meta-analysis. Clinical Infectious Diseases, 2014;60(7):1120-7. Available from: http://www.ncbi.nlm.nih.gov/pubmed/25516189 [Accessed December 13th2019].

10. Figueroa C, Johnson C, Verster A, Baggaley R. Attitudes and Acceptability on HIV Self-testing Among Key Populations: A Literature Review. AIDS Behaviour, 2015 Nov ;19(11):1949-65. Available from: http://www.ncbi.nlm.nih.gov/pubmed/26054390. [Accessed March 23rd 2019]. 
11. WHO,Consolidated Guidelines on HIV Testing Services, 2015. Available from: http://www.who.int/hiv/pub/vct/hiv-self-testingguidelines/en/. [Accessed October 20th 2019].

12. Katz DA, Golden MR, Hughes JP, Farquhar C, Stekler JD. HIV Self-testing increases HIV testing frequency in high-risk men who have sex with men: A randomized controlled trial. J Acquired Immune Deficiency Syndrome. 2018;78(5):505-12.

13. NASCOP. Guidelines for HIV Testing and Counselling in Kenya. 2010;(October):x-48. Available from https://www.who.int/hiv/topics/vct/policy/KenyaGuidelines_Final2009.pdf. [Accessed March 12th 2019].

14. Lippman SA, Lane T, Rabede O, Gilmore H, Chen YH, Mlotshwa N, et al. High Acceptability and Increased HIV-Testing Frequency After Introduction of HIV Self-Testing and Network Distribution Among South African MSM. J Acquired Immune Deficiency Syndrome. 2018;77(3):279-87.

15. Ng OT, Chow AL, Lee VJ, Chen MIC, Win MK, Tan HH, et al. Accuracy and User-Acceptability of HIV Self-Testing Using an Oral FluidBased HIV Rapid Test. PLoS One. 2012;7(9):3-10. Available from https://www.ncbi.nlm.nih.gov/pmc/articles/PMC3444491/. [Accessed September 18th 2019].

16. Heard AC, Brown AN. Public readiness for HIV self-testing in Kenya. AIDS Care - Psychol Socio-Medical AIDS/HIV. 2016;28 (12):152832.

17. Tun W, Vu L, Dirisu O, Sekoni A, Shoyemi E, Njab J, et al. Uptake of HIV self-testing and linkage to treatment among men who have sex with men (MSM) in Nigeria: A pilot programme using key opinion leaders to reach MSM. 2018 ; Available from: http://onlinelibrary.wiley.com/doi/10.1002/jia2.25124/full. [Accessed April 29th, 2019$]$.

18. Kalibala S, Tun W, Cherutich P, Nganga A, Oweya E, Oluoch P. Factors associated with acceptability of HIV self-testing among health care workers in Kenya. AIDS Behaviour, 2014 ;18 Suppl 4(Suppl 4):S405-14. Available from: http://www.ncbi.nlm.nih.gov/pubmed/24974123. [Accessed October 26th, 2019].

19. Ngure K, Heffron R, Mugo N, Thomson KA, Irungu E, Njuguna N, et al. Feasibility and acceptability of HIV self-testing among preexposure prophylaxis users in Kenya. J International AIDS Society. 2017;20(1):21234. Available from: http://www.ncbi.nlm.nih.gov/pubmed/28362073. [Accessed November 13th, 2019].

20. Chipungu J, Bosomprah S, Zanolini A, Thimurthy H, Chilengi R, Sharma A, et al. Understanding linkage to care with HIV self-test approach in Lusaka, Zambia - A mixed method approach. Abrams WR, editor. PLoS One 2017;12(11):e0187998. Available from: https://dx.plos.org/10.1371/journal.pone.0187998. [Accessed January 2020].

21. Hogg RS. Understanding the HIV care continuum. Lancet HIV. 2018;5(6):e269-70. Available from; https://www.cdc.gov/hiv/pdf/library/factsheets/cdc-hiv-care-continuum.pdf . [Accessed March 18th 2020].

22. Qin Y, Tang W, Nowacki A, Mollan K, Reifeis SA, Hudgens MG, et al. Benefits and Potential Harms of Human Immunodeficiency Virus Self-Testing Among Men Who Have Sex With Men in China. Journal Sexually Transmitted Disease 2017;44(4):233-8. Available from: http://www.ncbi.nlm.nih.gov/pubmed/28282650. [Accessed April 18th 2020].

23. Zhong F, Tang W, Cheng W, Lin P, Wu Q, Cai Y, et al. Acceptability and feasibility of a social entrepreneurship testing model to promote HIV self-testing and linkage to care among men who have sex with men. HIV Medicine 2017, 18(5):376-82. Available from: http://www.ncbi.nlm.nih.gov/pubmed/27601301. [Accessed October 14th 2020].

24. Volk JE, Lippman SA, Grinsztejn B, Lama JR, Fernandes NM, Gonzales P, et al. Acceptability and feasibility of HIV self-testing among men who have sex with men in Peru and Brazil. International Journal of STD AIDS 2016, 27(7):531-6. Available from: http://www.ncbi.nlm.nih.gov/pubmed/25971262. [Accessed May 10th 2020].

25. Heard AC, Brown AN. Public readiness for HIV self-testing in Kenya. AIDS Care - Psychol Socio-Medical Asp AIDS/HIV. 2016;28 (12):1528-32.

26. Wei C, Yan L, Li J, Su X, Lippman S, Yan H. Which user errors matter during HIV self-testing? A qualitative participant observation study of men who have sex with men (MSM) in China. BMC Public Health. 2018;18(1):1108. Available from.

https://bmcpublichealth.biomedcentral.com/articles/10.1186/s12889-018-6007-3. [Accessed July 2nd 2019]. 
27. Peck RB, Lim JM, van Rooyen H, Mukoma W, Chepuka L, Bansil P, et al. What Should the Ideal HIV Self-Test Look Like? A Usability Study of Test Prototypes in Unsupervised HIV Self-Testing in Kenya, Malawi, and South Africa. AIDS Behaviour 2014 J;18(S4):422-32. Available from: http://www.ncbi.nlm.nih.gov/pubmed/24947852. [Accessed April 29th 2020].

28. UNAIDS. 90-90-90: An ambitious treatment target to help end the AIDS epidemic. 2020. Available from: http://www.unaids.org/sites/default/files/media_asset/90-90-90_en.pdf. [Accessed May 1st 2019].

\section{Tables}

Table 1. Demographics, Socio-economic \& HIV Risk characteristics of participants. 


\begin{tabular}{|c|c|c|}
\hline \multicolumn{3}{|l|}{ Country of birth } \\
\hline & Frequency & Percent (\%) \\
\hline Kenya & 323 & 92.6 \\
\hline Uganda & 14 & 4.0 \\
\hline DRC & 4 & 1.1 \\
\hline Rwanda & 4 & 1.1 \\
\hline Tanzania & 2 & .6 \\
\hline Nigeria & 1 & .3 \\
\hline Cote D'voire & 1 & .3 \\
\hline Total & 349 & 100.0 \\
\hline \multicolumn{3}{|l|}{ Education level } \\
\hline & Frequency & Percent (\%) \\
\hline Never & 5 & 1.4 \\
\hline Primary School & 35 & 9.6 \\
\hline Secondary School & 182 & 50.1 \\
\hline Tertiary & 141 & 38.8 \\
\hline Total & 363 & 100.0 \\
\hline \multicolumn{3}{|l|}{ Currently employed } \\
\hline & Frequency & Percent (\%) \\
\hline No & 203 & 63.0 \\
\hline Yes & 119 & 37.0 \\
\hline Total & 322 & 100.0 \\
\hline \multicolumn{3}{|l|}{ Monthly income } \\
\hline & Frequency & Percent (\%) \\
\hline Less than 60 USD & 104 & 49.3 \\
\hline $60-250$ USD & 83 & 39.3 \\
\hline 251 - 750 USD & 19 & 9.0 \\
\hline 750 + USD & 5 & 2.4 \\
\hline Total & 211 & 100.0 \\
\hline Identity MSW & Frequency & Percent (\%) \\
\hline No & 172 & 50.0 \\
\hline Yes & 172 & 50.0 \\
\hline Total & 344 & 100.0 \\
\hline \multicolumn{3}{|l|}{ Sexual Orientation } \\
\hline & Frequency & Percent (\%) \\
\hline Homosexual & 228 & 66.3 \\
\hline Bisexual & 95 & 27.6 \\
\hline Heterosexual & 8 & 2.3 \\
\hline
\end{tabular}

Page 13/21 


\begin{tabular}{|c|c|c|}
\hline Other & 13 & 3.8 \\
\hline Total & 344 & 100.0 \\
\hline \multicolumn{3}{|l|}{ Marital status } \\
\hline & Frequency & Percent (\%) \\
\hline Single & 306 & 86.4 \\
\hline Widower & 5 & 1.4 \\
\hline Married & 29 & 8.2 \\
\hline Divorced/Separated & 14 & 4.0 \\
\hline Total & 354 & 100.0 \\
\hline \multicolumn{3}{|l|}{ If ever married } \\
\hline & Frequency & Percent (\%) \\
\hline Man & 57 & 68.7 \\
\hline Woman & 24 & 28.9 \\
\hline Both Man and woman & 2 & 2.4 \\
\hline Total & 83 & 100.0 \\
\hline \multicolumn{3}{|c|}{ Number of Sexual partners last 6 months } \\
\hline & Frequency & Percent (\%) \\
\hline One & 74 & 21.1 \\
\hline Two & 118 & 33.6 \\
\hline Multiple & 140 & 39.9 \\
\hline None & 19 & 5.4 \\
\hline Total & 351 & 100.0 \\
\hline \multicolumn{3}{|l|}{ Use condom during sex } \\
\hline & Frequency & Percent (\%) \\
\hline No & 31 & 8.8 \\
\hline Yes & 320 & 91.2 \\
\hline Total & 351 & 100.0 \\
\hline \multicolumn{3}{|l|}{ Condom use frequency } \\
\hline & Frequency & Percent (\%) \\
\hline Always & 186 & 57.4 \\
\hline Most of the time & 89 & 27.5 \\
\hline Sometimes & 46 & 14.2 \\
\hline Never & 3 & .9 \\
\hline Total & 324 & 100.0 \\
\hline \multicolumn{3}{|l|}{ Prefer top or bottom } \\
\hline & Frequency & Percent (\%) \\
\hline Top & 132 & 37.9 \\
\hline Bottom & 73 & 21.0 \\
\hline Both/versatile & 143 & 41.1 \\
\hline
\end{tabular}

Page 14/21 


\begin{tabular}{|c|c|c|}
\hline Total & 348 & 100.0 \\
\hline \multicolumn{3}{|c|}{ Frequency of condom use during anal sex after alcohol/hard drug use } \\
\hline & Frequency & Percent (\%) \\
\hline Always & 158 & 51.6 \\
\hline Most of the time & 58 & 19.0 \\
\hline Some times & 49 & 16.0 \\
\hline Never & 41 & 13.4 \\
\hline Total & 306 & 100.0 \\
\hline
\end{tabular}

Table 2 Results on HIV self-test. 


\begin{tabular}{|c|c|c|c|c|c|c|c|c|c|c|}
\hline & & & \multicolumn{2}{|c|}{$\begin{array}{l}\text { Used HIV test kit } \\
\text { before. }\end{array}$} & \multirow[t]{3}{*}{ Total } & \multirow{3}{*}{$\begin{array}{l}\text { Chi- } \\
\text { Square } \\
\text { Tests } \\
\text { P-Value }\end{array}$} & \multicolumn{4}{|l|}{ Risk Estimate } \\
\hline & & & \multirow[t]{2}{*}{ No } & \multirow[t]{2}{*}{ Yes } & & & \multirow[t]{2}{*}{ Value } & \multicolumn{2}{|c|}{$\begin{array}{l}95 \% \\
\text { Confidence } \\
\text { Interval }\end{array}$} & \\
\hline & & & & & & & & & Lower & Upper \\
\hline \multirow[t]{2}{*}{$\begin{array}{l}\text { Ever tested } \\
\text { for HIV/AIDs }\end{array}$} & No & & $\begin{array}{l}12 \\
(66.6)\end{array}$ & $6(33.3)$ & $18(5)$ & 0.227 & $\begin{array}{l}\text { Odds Ratio } \\
\text { for Ever } \\
\text { tested for } \\
\text { HIV/AIDs } \\
\text { (No / Yes) }\end{array}$ & 1.733 & 0.636 & 4.721 \\
\hline & Yes & n (\%) & $\begin{array}{l}187 \\
(53.6)\end{array}$ & $162(46.4)$ & 349 (95) & & $\begin{array}{l}\text { For cohort } \\
\text { Used HIV } \\
\text { test kit } \\
\text { before = No }\end{array}$ & 1.244 & 0.885 & 1.75 \\
\hline Total & & n (\%) & $\begin{array}{l}199 \\
(54.2)\end{array}$ & $\begin{array}{l}168 \\
(45.8)\end{array}$ & 367 & & $\begin{array}{l}\text { For cohort } \\
\text { Used HIV } \\
\text { test kit } \\
\text { before = Yes }\end{array}$ & 0.718 & 0.37 & 1.394 \\
\hline \multirow[t]{2}{*}{$\begin{array}{l}\text { If yes how } \\
\text { often do you } \\
\text { test for } \\
\text { HIV/AIDS }\end{array}$} & $\begin{array}{l}\text { Every } 3 \\
\text { months }\end{array}$ & n (\%) & $\begin{array}{l}122 \\
(49.6)\end{array}$ & $\begin{array}{l}124 \\
(50.4)\end{array}$ & $246(67)$ & 0.011 & $\begin{array}{l}\text { Odds Ratio } \\
\text { for If yes } \\
\text { how often } \\
\text { do you test } \\
\text { for } \\
\text { HIV/AIDS } \\
\text { (Every } 3 \\
\text { months / } \\
\text { Greater than } \\
3 \text { months) }\end{array}$ & 0.562 & 0.36 & 0.879 \\
\hline & $\begin{array}{l}\text { Greater } \\
\text { than } 3 \\
\text { months }\end{array}$ & n (\%) & $77(63.6)$ & $44(36.4)$ & 121(33) & & $\begin{array}{l}\text { For cohort } \\
\text { Used HIV } \\
\text { test kit } \\
\text { before = No }\end{array}$ & 0.779 & 0.648 & 0.937 \\
\hline Total & & n (\%) & $\begin{array}{l}199 \\
(54.2)\end{array}$ & 168(45.8) & 367 & & $\begin{array}{l}\text { For cohort } \\
\text { Used HIV } \\
\text { test kit } \\
\text { before = Yes }\end{array}$ & 1.386 & 1.062 & 1.809 \\
\hline \multirow[t]{2}{*}{$\begin{array}{l}\text { Results of } \\
\text { the most } \\
\text { recent HIV } \\
\text { test }\end{array}$} & Negative & n (\%) & $\begin{array}{l}146 \\
(52.1)\end{array}$ & $\begin{array}{l}134 \\
(47.9)\end{array}$ & $280(76)$ & 0.151 & $\begin{array}{l}\text { Odds Ratio } \\
\text { for Results } \\
\text { of the most } \\
\text { recent HIV } \\
\text { test } \\
\text { (Negative / } \\
\text { Positive) }\end{array}$ & 0.699 & 0.428 & 1.141 \\
\hline & Positive & $\mathrm{n}(\%)$ & $\begin{array}{l}53 \\
(60.9)\end{array}$ & $34(39.1)$ & $87(24)$ & & $\begin{array}{l}\text { For cohort } \\
\text { Used HIV } \\
\text { test kit } \\
\text { before = No }\end{array}$ & 0.856 & 0.699 & 1.048 \\
\hline Total & & n (\%) & $\begin{array}{l}199 \\
(54.2)\end{array}$ & $\begin{array}{l}168 \\
(45.8)\end{array}$ & 367 & & $\begin{array}{l}\text { For cohort } \\
\text { Used HIV } \\
\text { test kit } \\
\text { before = Yes }\end{array}$ & 1.225 & 0.917 & 1.636 \\
\hline \multirow[t]{2}{*}{$\begin{array}{l}\text { Ever heard } \\
\text { of window } \\
\text { period }\end{array}$} & No & $\mathrm{n}(\%)$ & $\begin{array}{l}111 \\
(57.5)\end{array}$ & $82(42.5)$ & $193(53)$ & 0.183 & $\begin{array}{l}\text { Odds Ratio } \\
\text { for Ever } \\
\text { heard of } \\
\text { window } \\
\text { period (No / } \\
\text { Yes) }\end{array}$ & 1.323 & 0.876 & 1.997 \\
\hline & Yes & n (\%) & $\begin{array}{l}88 \\
(50.6)\end{array}$ & $86(49.4)$ & $174(47)$ & & $\begin{array}{l}\text { For cohort } \\
\text { Used HIV } \\
\text { test kit } \\
\text { before = No }\end{array}$ & 1.137 & 0.94 & 1.376 \\
\hline Total & & $\mathrm{n}(\%)$ & 199 & 168 & 367 & & For cohort & 0.86 & 0.688 & 1.074 \\
\hline
\end{tabular}


(54.2)

(45.8)

Used HIV

test kit

before $=$ Yes

\begin{tabular}{|c|c|c|c|c|c|}
\hline \multirow[t]{2}{*}{$\begin{array}{l}\text { If yes } \\
\text { considered } \\
\text { window } \\
\text { period in } \\
\text { deciding } \\
\text { when to test }\end{array}$} & No & n (\%) & $\begin{array}{l}116 \\
(58.6)\end{array}$ & $82(41.4)$ & 198 (54) \\
\hline & Yes & $\mathrm{n}(\%)$ & $\begin{array}{l}83 \\
(49.1)\end{array}$ & $86(50.9)$ & 169 (46) \\
\hline Total & & $\mathrm{n}(\%)$ & $\begin{array}{l}199 \\
(54.2)\end{array}$ & $\begin{array}{l}168 \\
(45.8)\end{array}$ & 367 \\
\hline
\end{tabular}

Odds Ratio $\quad 1.466 \quad 0.969 \quad 2.216$

for If yes

considered

window

period in

deciding

when to test

(No / Yes)

$\begin{array}{llll}\text { For cohort } \quad 1.193 \quad 0.983 & 1.447\end{array}$

Used HIV

test kit

before $=$ No

For cohort $\quad 0.814 \quad 0.652 \quad 1.016$

Used HIV

test kit

before $=$ Yes

\begin{tabular}{|c|c|c|c|c|c|c|c|c|c|}
\hline $\begin{array}{l}\text { Consider } \\
\text { taking up } \\
\text { HIV self-test } \\
\text { as one of } \\
\text { the HIV } \\
\text { combination } \\
\text { prevention } \\
\text { strategy }\end{array}$ & No & n (\%) & $\begin{array}{l}53 \\
(60.9)\end{array}$ & $34(39.1)$ & 87 (24) & 0.151 & $\begin{array}{l}\text { Odds Ratio } \\
\text { for Consider } \\
\text { taking up } \\
\text { HIV self-test } \\
\text { as one of } \\
\text { the HIV } \\
\text { combination } \\
\text { prevention } \\
\text { strategy (No } \\
\text { / Yes) }\end{array}$ & 1.431 & 0.876 \\
\hline
\end{tabular}

$\begin{array}{llll}\text { Yes } & \mathrm{n}(\%) & 146 & 134 \\ & (52.1) & (47.9) & 280(76)\end{array}$

$\begin{array}{llll}\text { For cohort } \quad 1.168 & 0.954 & 1.43\end{array}$

Used HIV

test kit

before $=$ No

$\begin{array}{llll}\text { Total } & \mathrm{n}(\%) & \begin{array}{l}199 \\ (54.2)\end{array} & \begin{array}{l}168 \\ (45.8)\end{array}\end{array}$

$\begin{array}{llll}\text { For cohort } \quad 0.817 \quad 0.611 & 1.091\end{array}$

Used HIV

test kit

before $=$ Yes

\begin{tabular}{|c|c|c|c|c|c|c|c|c|c|c|}
\hline $\begin{array}{l}\text { If HIV } \\
\text { positive } \\
\text { through HIV } \\
\text { self-test, } \\
\text { would you } \\
\text { go for a } \\
\text { confirmatory } \\
\text { test }\end{array}$ & No & n (\%) & $\begin{array}{l}42 \\
(56.0)\end{array}$ & $33(44.0)$ & 75 (20) & 0.031 & $\begin{array}{l}\text { Odds Ratio } \\
\text { for Consider } \\
\text { taking up } \\
\text { HIV self-test } \\
\text { as one of } \\
\text { the HIV } \\
\text { combination } \\
\text { prevention } \\
\text { strategy (No } \\
\text { / Yes) }\end{array}$ & 0.562 & 0.36 & 0.879 \\
\hline
\end{tabular}

\begin{tabular}{|c|c|c|c|c|c|c|c|c|c|c|}
\hline & \multirow[b]{2}{*}{ Yes } & \multirow[b]{2}{*}{$\mathrm{n}(\%)$} & \multirow[b]{2}{*}{$\begin{array}{l}157 \\
(53.8)\end{array}$} & \multirow[b]{2}{*}{$\begin{array}{l}135 \\
(46.2)\end{array}$} & \multirow[b]{2}{*}{$292(80)$} & & \multirow[b]{2}{*}{$\begin{array}{l}\text { For cohort } \\
\text { Used HIV } \\
\text { test kit } \\
\text { before = No }\end{array}$} & \multirow[b]{2}{*}{0.779} & \multirow[b]{2}{*}{0.648} & \multirow[b]{2}{*}{0.937} \\
\hline & & & & & & & & & & \\
\hline Total & & $\mathrm{n}(\%)$ & $\begin{array}{l}199 \\
(54.2)\end{array}$ & $\begin{array}{l}168 \\
(45.8)\end{array}$ & 367 & & $\begin{array}{l}\text { For cohort } \\
\text { Used HIV } \\
\text { test kit } \\
\text { before = Yes }\end{array}$ & 1.386 & 1.062 & 1.809 \\
\hline \multirow[t]{2}{*}{$\begin{array}{l}\text { If yes after } \\
\text { how long } \\
\text { would you } \\
\text { go for a } \\
\text { confirmatory } \\
\text { test }\end{array}$} & $\begin{array}{l}\text { One month } \\
\text { or less }\end{array}$ & n (\%) & $\begin{array}{l}182 \\
(54.8)\end{array}$ & $\begin{array}{l}150 \\
(45.2)\end{array}$ & 332 (92) & 0.898 & $\begin{array}{l}\text { Odds Ratio } \\
\text { for If yes } \\
\text { after how } \\
\text { long would } \\
\text { you go for a } \\
\text { confirmatory } \\
\text { test (One } \\
\text { month or } \\
\text { less / Won't } \\
\text { go) }\end{array}$ & 1.052 & 0.485 & 2.279 \\
\hline & Won't go & $\mathrm{n}(\%)$ & $\begin{array}{l}15 \\
(53.6)\end{array}$ & $13(46.4)$ & $28(8)$ & & $\begin{array}{l}\text { For cohort } \\
\text { Used HIV }\end{array}$ & 1.023 & 0.715 & 1.464 \\
\hline
\end{tabular}

Page $17 / 21$ 


\begin{tabular}{|c|c|c|c|c|c|c|c|c|c|c|}
\hline & & & & & & & $\begin{array}{l}\text { test kit } \\
\text { before = No }\end{array}$ & & & \\
\hline \multicolumn{2}{|l|}{ Total } & n (\%) & $\begin{array}{l}197 \\
(54.7)\end{array}$ & $\begin{array}{l}163 \\
(45.3)\end{array}$ & 360 & & $\begin{array}{l}\text { For cohort } \\
\text { Used HIV } \\
\text { test kit } \\
\text { before = Yes }\end{array}$ & 0.973 & 0.643 & 1.474 \\
\hline \multirow[t]{2}{*}{$\begin{array}{l}\text { If you test } \\
\text { positive } \\
\text { would you } \\
\text { use } \\
\text { protection or } \\
\text { condoms } \\
\text { with your } \\
\text { partner }\end{array}$} & No & n (\%) & $\begin{array}{l}36 \\
(69.2)\end{array}$ & $16(30.8)$ & $52(14)$ & 0.019 & $\begin{array}{l}\text { Odds Ratio } \\
\text { for If you } \\
\text { test positive } \\
\text { would you } \\
\text { use } \\
\text { protection or } \\
\text { condoms } \\
\text { with your } \\
\text { partner (No / } \\
\text { Yes) }\end{array}$ & 2.098 & 1.119 & 3.936 \\
\hline & Yes & n (\%) & $\begin{array}{l}163 \\
(51.7)\end{array}$ & $\begin{array}{l}152 \\
(48.3)\end{array}$ & $315(86)$ & & $\begin{array}{l}\text { For cohort } \\
\text { Used HIV } \\
\text { test kit } \\
\text { before = No }\end{array}$ & 1.338 & 1.084 & 1.651 \\
\hline \multicolumn{2}{|l|}{ Total } & n (\%) & $\begin{array}{l}199 \\
(54.2)\end{array}$ & $\begin{array}{l}168 \\
(45.8)\end{array}$ & 367 & & $\begin{array}{l}\text { For cohort } \\
\text { Used HIV } \\
\text { test kit } \\
\text { before }=\text { Yes }\end{array}$ & 0.638 & 0.418 & 0.974 \\
\hline \multirow[t]{2}{*}{$\begin{array}{l}\text { Would go } \\
\text { for } \\
\text { counselling } \\
\text { after } \\
\text { positive } \\
\text { result }\end{array}$} & No & $\mathrm{n}(\%)$ & $\begin{array}{l}115 \\
(58.1)\end{array}$ & 83 (41.9) & $198(54)$ & 0.108 & $\begin{array}{l}\text { Odds Ratio } \\
\text { for Would } \\
\text { go for } \\
\text { counselling } \\
\text { after } \\
\text { positive } \\
\text { result (No / } \\
\text { Yes) }\end{array}$ & 1.402 & 0.928 & 2.119 \\
\hline & Yes & n (\%) & $\begin{array}{l}84 \\
(49.7)\end{array}$ & $85(50.3)$ & $169(46)$ & & $\begin{array}{l}\text { For cohort } \\
\text { Used HIV } \\
\text { test kit } \\
\text { before }=\text { No }\end{array}$ & 1.169 & 0.964 & 1.416 \\
\hline \multicolumn{2}{|l|}{ Total } & n (\%) & $\begin{array}{l}199 \\
(54.2)\end{array}$ & $\begin{array}{l}168 \\
(45.8)\end{array}$ & 367 & & $\begin{array}{l}\text { For cohort } \\
\text { Used HIV } \\
\text { test kit } \\
\text { before = Yes }\end{array}$ & 0.833 & 0.667 & 1.041 \\
\hline \multirow[t]{2}{*}{$\begin{array}{l}\text { If negative } \\
\text { test result } \\
\text { would you } \\
\text { use } \\
\text { condoms } \\
\text { with your } \\
\text { partner }\end{array}$} & No & n (\%) & $\begin{array}{l}29 \\
(69.0)\end{array}$ & $13(31)$ & $42(11)$ & 0.04 & $\begin{array}{l}\text { Odds Ratio } \\
\text { for If } \\
\text { negative test } \\
\text { result would } \\
\text { you use } \\
\text { condoms } \\
\text { with your } \\
\text { partner (No / } \\
\text { Yes) }\end{array}$ & 2.034 & 1.021 & 4.053 \\
\hline & Yes & $\mathrm{n}(\%)$ & $\begin{array}{l}170 \\
(52.3)\end{array}$ & $\begin{array}{l}155 \\
(47.7)\end{array}$ & $325(89)$ & & $\begin{array}{l}\text { For cohort } \\
\text { Used HIV } \\
\text { test kit } \\
\text { before = No }\end{array}$ & 1.32 & 1.051 & 1.657 \\
\hline \multicolumn{2}{|l|}{ Total } & $\mathrm{n}(\%)$ & $\begin{array}{l}199 \\
(54.2)\end{array}$ & $\begin{array}{l}168 \\
(45.8)\end{array}$ & 367 & & $\begin{array}{l}\text { For cohort } \\
\text { Used HIV } \\
\text { test kit } \\
\text { before = Yes }\end{array}$ & 0.649 & 0.407 & 1.034 \\
\hline \multirow[t]{2}{*}{$\begin{array}{l}\text { Ever heard } \\
\text { of HIV self- } \\
\text { test }\end{array}$} & No & $\mathrm{n}(\%)$ & $\begin{array}{l}89 \\
(65.4)\end{array}$ & 47 (34.6) & $136(37)$ & 0.001 & $\begin{array}{l}\text { Odds Ratio } \\
\text { for Ever } \\
\text { heard of HIV } \\
\text { self-test (No } \\
\text { / Yes) }\end{array}$ & 2.083 & 1.345 & 3.227 \\
\hline & Yes & $\mathrm{n}(\%)$ & $\begin{array}{l}110 \\
(47.6)\end{array}$ & $121(52.4)$ & $231(63)$ & & $\begin{array}{l}\text { For cohort } \\
\text { Used HIV } \\
\text { test kit } \\
\text { before = No }\end{array}$ & 1.374 & 1.145 & 1.649 \\
\hline
\end{tabular}




\begin{tabular}{|c|c|c|c|c|c|c|c|c|c|c|}
\hline Total & & n (\%) & $\begin{array}{l}199 \\
(54.2)\end{array}$ & $\begin{array}{l}168 \\
(45.8)\end{array}$ & 367 & & $\begin{array}{l}\text { For cohort } \\
\text { Used HIV } \\
\text { test kit } \\
\text { before = Yes }\end{array}$ & 0.66 & 0.508 & 0.857 \\
\hline \multirow[t]{2}{*}{$\begin{array}{l}\text { Ever heard } \\
\text { of oral HIV } \\
\text { Self-test }\end{array}$} & No & n (\%) & $\begin{array}{l}107 \\
(66.0)\end{array}$ & $55(34.0)$ & $162(44)$ & $<0.0001$ & $\begin{array}{l}\text { Odds Ratio } \\
\text { for Ever } \\
\text { heard of oral } \\
\text { HIV Self-test } \\
\text { (No / Yes) }\end{array}$ & 2.39 & 1.561 & 3.659 \\
\hline & Yes & n (\%) & $\begin{array}{l}92 \\
(44.9)\end{array}$ & $\begin{array}{l}113 \\
(55.1)\end{array}$ & 205 (56) & & $\begin{array}{l}\text { For cohort } \\
\text { Used HIV } \\
\text { test kit } \\
\text { before }=\text { No }\end{array}$ & 1.472 & 1.22 & 1.776 \\
\hline Total & & n (\%) & $\begin{array}{l}199 \\
(54.2)\end{array}$ & $\begin{array}{l}168 \\
(45.8)\end{array}$ & 367 & & $\begin{array}{l}\text { For cohort } \\
\text { Used HIV } \\
\text { test kit } \\
\text { before = Yes }\end{array}$ & 0.616 & 0.481 & 0.789 \\
\hline \multirow[t]{2}{*}{$\begin{array}{l}\text { Ever heard } \\
\text { of blood } \\
\text { sample HIV } \\
\text { Self-test }\end{array}$} & No & n (\%) & $\begin{array}{l}83 \\
(76.9)\end{array}$ & $25(23.1)$ & 108 (29) & $<0.0001$ & $\begin{array}{l}\text { Odds Ratio } \\
\text { for Heard of } \\
\text { blood } \\
\text { sample HIV } \\
\text { Self-test (No } \\
\text { / Yes) }\end{array}$ & 4.093 & 2.458 & 6.814 \\
\hline & Yes & n (\%) & $\begin{array}{l}116 \\
(44.8)\end{array}$ & $\begin{array}{l}143 \\
(55.2)\end{array}$ & $259(71)$ & & $\begin{array}{l}\text { For cohort } \\
\text { Used HIV } \\
\text { test kit } \\
\text { before }=\text { No }\end{array}$ & 1.716 & 1.447 & 2.034 \\
\hline Total & & n (\%) & $\begin{array}{l}199 \\
(54.2)\end{array}$ & $\begin{array}{l}168 \\
(45.8)\end{array}$ & 367 & & $\begin{array}{l}\text { For cohort } \\
\text { Used HIV } \\
\text { test kit } \\
\text { before = Yes }\end{array}$ & 0.419 & 0.292 & 0.601 \\
\hline \multirow[t]{2}{*}{$\begin{array}{l}\text { Would prefer } \\
\text { to use the } \\
\text { Oral or } \\
\text { Blood self- } \\
\text { test kit }\end{array}$} & $\begin{array}{l}\text { Oral self- } \\
\text { test kit }\end{array}$ & n (\%) & $\begin{array}{l}77 \\
(61.1)\end{array}$ & 49 (38.9) & $126(41)$ & 0.039 & $\begin{array}{l}\text { Odds Ratio } \\
\text { for Would } \\
\text { prefer to use } \\
\text { the Oral or } \\
\text { Blood self- } \\
\text { test kit (Oral } \\
\text { self-test kit / } \\
\text { Blood self- } \\
\text { test kit) }\end{array}$ & 1.624 & 1.024 & 2.578 \\
\hline & $\begin{array}{l}\text { Blood self- } \\
\text { test kit }\end{array}$ & n (\%) & $\begin{array}{l}89 \\
(49.2)\end{array}$ & $92(50.8)$ & $181(59)$ & & $\begin{array}{l}\text { For cohort } \\
\text { Used HIV } \\
\text { test kit } \\
\text { before }=\text { No }\end{array}$ & 1.243 & 1.014 & 1.523 \\
\hline Total & & n (\%) & $\begin{array}{l}166 \\
(54.1)\end{array}$ & $\begin{array}{l}141 \\
(45.9)\end{array}$ & 307 & & $\begin{array}{l}\text { For cohort } \\
\text { Used HIV } \\
\text { test kit } \\
\text { before = Yes }\end{array}$ & 0.765 & 0.589 & 0.994 \\
\hline \multirow[t]{2}{*}{$\begin{array}{l}\text { What do you } \\
\text { think of the } \\
\text { current cost }\end{array}$} & Affordable & n (\%) & $\begin{array}{l}107 \\
(69.0)\end{array}$ & $48(31)$ & 155 (42) & $<0.0001$ & $\begin{array}{l}\text { Odds Ratio } \\
\text { for What do } \\
\text { you think of } \\
\text { the current } \\
\text { cost } \\
\text { (Affordable } \\
\text { / Expensive) }\end{array}$ & 2.908 & 1.881 & 4.495 \\
\hline & Expensive & n (\%) & $\begin{array}{l}92 \\
(43.4)\end{array}$ & $\begin{array}{l}120 \\
(56.6)\end{array}$ & $212(58)$ & & $\begin{array}{l}\text { For cohort } \\
\text { Used HIV } \\
\text { test kit } \\
\text { before }=\text { No }\end{array}$ & 1.591 & 1.32 & 1.917 \\
\hline Total & & n (\%) & $\begin{array}{l}199 \\
(54.2)\end{array}$ & $\begin{array}{l}168 \\
(45.8)\end{array}$ & 367 & & $\begin{array}{l}\text { For cohort } \\
\text { Used HIV } \\
\text { test kit } \\
\text { before = Yes }\end{array}$ & 0.547 & 0.421 & 0.712 \\
\hline $\begin{array}{l}\text { Frequency } \\
\text { of STI }\end{array}$ & $0-3$ months & $\mathrm{n}(\%)$ & $\begin{array}{l}141 \\
(50.4)\end{array}$ & $\begin{array}{l}139 \\
(49.6)\end{array}$ & 280 (77) & 0.005 & $\begin{array}{l}\text { Odds Ratio } \\
\text { for }\end{array}$ & 0.49 & 0.295 & 0.814 \\
\hline
\end{tabular}

Page 19/21 


\begin{tabular}{|c|c|c|c|c|c|c|c|c|c|c|c|}
\hline \multicolumn{7}{|l|}{ screening } & & \multicolumn{4}{|l|}{$\begin{array}{l}\text { Frequency } \\
\text { of STI } \\
\text { screening (0- } \\
3 \text { months / } \\
\text { Over } 3 \\
\text { months) }\end{array}$} \\
\hline & \multicolumn{2}{|c|}{$\begin{array}{l}\text { Over } 3 \\
\text { months }\end{array}$} & n (\%) & $\begin{array}{l}58 \\
(67.4)\end{array}$ & $28(32.6)$ & $86(23)$ & & $\begin{array}{l}\text { For cohort } \\
\text { Used HIV } \\
\text { test kit } \\
\text { before = No }\end{array}$ & 0.747 & 0.619 & 0.9 \\
\hline \multicolumn{3}{|l|}{ Total } & n (\%) & $\begin{array}{l}199 \\
(54.4)\end{array}$ & $\begin{array}{l}167 \\
(45.6)\end{array}$ & 366 & & $\begin{array}{l}\text { For cohort } \\
\text { Used HIV } \\
\text { test kit } \\
\text { before = Yes }\end{array}$ & 1.525 & 1.1 & 2.113 \\
\hline \multirow{4}{*}{$\begin{array}{l}\text { Preference } \\
\text { point of } \\
\text { picking the } \\
\text { oral HIV self- } \\
\text { test kit } \\
\text { /distribution }\end{array}$} & \multicolumn{2}{|c|}{ Private } & $\mathrm{n}(\%)$ & $43(58.1)$ & 31 (41.9) & $74(23.1)$ & 0.196 & & & & \\
\hline & \multicolumn{2}{|c|}{ Government } & n (\%) & $33(47.1)$ & $37(52.9)$ & 70 (21.9) & & & & & \\
\hline & \multicolumn{2}{|c|}{ NGO } & $\mathrm{n}(\%)$ & $90(53.3)$ & $79(46.7)$ & $\begin{array}{l}169 \\
(52.8)\end{array}$ & & & & & \\
\hline & \multicolumn{2}{|c|}{ Internet } & $\mathrm{n}(\%)$ & 6 (85.7) & 1 (14.3) & $7(2.2)$ & & & & & \\
\hline \multicolumn{3}{|l|}{ Total } & & $\begin{array}{l}172 \\
(53.8)\end{array}$ & 148(46.3) & 320 & & & & & \\
\hline \multirow{3}{*}{$\begin{array}{l}\text { If using self- } \\
\text { test for the } \\
\text { first time } \\
\text { would you } \\
\text { prefer to } \\
\text { have a } \\
\text { treatment } \\
\text { "buddy" }\end{array}$} & \multicolumn{2}{|l|}{ No } & $\mathrm{n}(\%)$ & $27(54)$ & $23(46)$ & $50(15.3)$ & 0.557 & & & & \\
\hline & \multicolumn{2}{|c|}{ Yes } & $\mathrm{n}(\%)$ & 149(54) & $127(46)$ & $\begin{array}{l}276 \\
(84.4)\end{array}$ & & & & & \\
\hline & \multicolumn{2}{|c|}{$\begin{array}{l}\text { Not } \\
\text { applicable }\end{array}$} & n (\%) & 0 & 10 & $1(0.3)$ & & & & & \\
\hline Total & & & $\mathrm{n}(\%)$ & $\begin{array}{l}176 \\
(53.8)\end{array}$ & $\begin{array}{l}151 \\
(46.2)\end{array}$ & 327 & & & & & \\
\hline \multirow{3}{*}{$\begin{array}{l}\text { Organization of } \\
\text { preference to } \\
\text { provide Test kit } \\
\text { Hotline }\end{array}$} & \multicolumn{3}{|c|}{ Public } & $\begin{array}{l}50 \\
(55 \%)\end{array}$ & $41(45 \%)$ & $91(29 \%)$ & 0.941 & & & & \\
\hline & \multicolumn{3}{|c|}{ Drop in Centre } & $\begin{array}{l}77 \\
(54 \%)\end{array}$ & $65(46 \%)$ & $142(45 \%)$ & & & & & \\
\hline & \multicolumn{3}{|c|}{$\begin{array}{l}\text { Private } \\
\text { hospitals }\end{array}$} & $\begin{array}{l}40 \\
(53 \%)\end{array}$ & 35 (47\%) & $75(24 \%)$ & & & & & \\
\hline \multirow{8}{*}{\multicolumn{2}{|c|}{$\begin{array}{l}\text { What would } \\
\text { prevent you from } \\
\text { using the HIV oral } \\
\text { test kit }\end{array}$}} & \multicolumn{2}{|c|}{ Not available } & $\begin{array}{l}22 \\
(46 \%)\end{array}$ & $26(54 \%)$ & 48 (15\%) & 0.600 & & & & \\
\hline & & \multicolumn{2}{|l|}{ Cost } & $\begin{array}{l}64 \\
(62 \%)\end{array}$ & 40 (38\%) & $\begin{array}{l}104 \\
(33 \%)\end{array}$ & & & & & \\
\hline & & \multicolumn{2}{|c|}{$\begin{array}{l}\text { Lack of } \\
\text { knowledge }\end{array}$} & $\begin{array}{l}51 \\
(51 \%)\end{array}$ & $49(49 \%)$ & $\begin{array}{l}100 \\
(32 \%)\end{array}$ & & & & & \\
\hline & & \multicolumn{2}{|l|}{ Fear } & $\begin{array}{l}20 \\
(47 \%)\end{array}$ & $23(53 \%)$ & $43(14 \%)$ & & & & & \\
\hline & & \multicolumn{2}{|l|}{ Other } & $4(80 \%)$ & $1(20 \%)$ & $5(1.6 \%)$ & & & & & \\
\hline & & \multicolumn{2}{|c|}{ Cost \& Fear } & $1(50 \%)$ & $1(50 \%)$ & $2(0.6 \%)$ & & & & & \\
\hline & & \multicolumn{2}{|c|}{$\begin{array}{l}\text { Lack of } \\
\text { knowledge }\end{array}$} & $2(67 \%)$ & $1(33 \%)$ & $3(1 \%)$ & & & & & \\
\hline & & \multicolumn{2}{|l|}{ Total } & $\begin{array}{l}168 \\
(54 \%)\end{array}$ & $\begin{array}{l}143 \\
(46 \%)\end{array}$ & 311 & & & & & \\
\hline
\end{tabular}

\section{Supplementary Files}


This is a list of supplementary files associated with this preprint. Click to download.

- HIVSTDatabaseMSM.xlsx

- HIVSTQuestionnaire.docx 